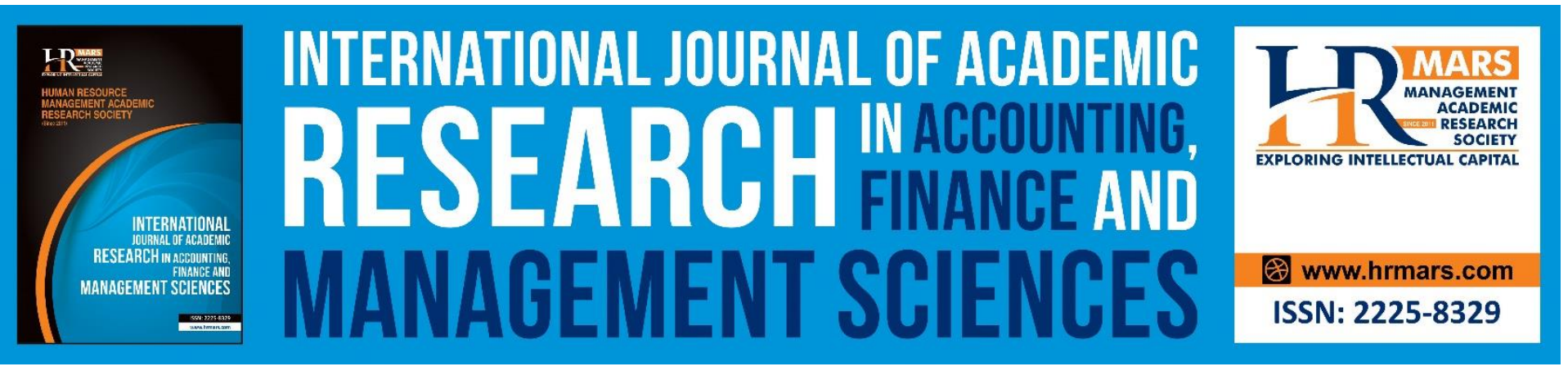

\title{
Effect of Adopting Hardship Allowance Academic Staffs in Jig-Jiga University, Somali Regional State, Ethiopia
}

\section{Regan Debebe Beluhu}

To Link this Article: http://dx.doi.org/10.6007/IJARAFMS/v10-i3/7935

DOI:10.6007/IJARAFMS /v10-i3/7935

Received: 19 June 2020, Revised: 23 July 2020, Accepted: 29 August 2020

Published Online: 26 September 2020

In-Text Citation: (Kamarunzaman, Shanthi, Nen, Zulkifli, \& Shamsuri, 2020)

To Cite this Article: Beluhu, R. D. . (2020). Effect of Adopting Hardship Allowance Academic Staffs in Jig-Jiga University, Somali Regional State, Ethiopia. International Journal of Academic Research in Accounting, Finance and Management Sciences. 10(3), 365-379.

\section{Copyright: (c) 2020 The Author(s)}

Published by Human Resource Management Academic Research Society (www.hrmars.com)

This article is published under the Creative Commons Attribution (CC BY 4.0) license. Anyone may reproduce, distribute, translate and create derivative works of this article (for both commercial and non-commercial purposes), subject to full attribution to the original publication and authors. The full terms of this license may be seen at: http://creativecommons.org/licences/by/4.0/legalcode

Vol. 10, No. 3, 2020, Pg. 365 - 379

Full Terms \& Conditions of access and use can be found at http://hrmars.com/index.php/pages/detail/publication-ethics 


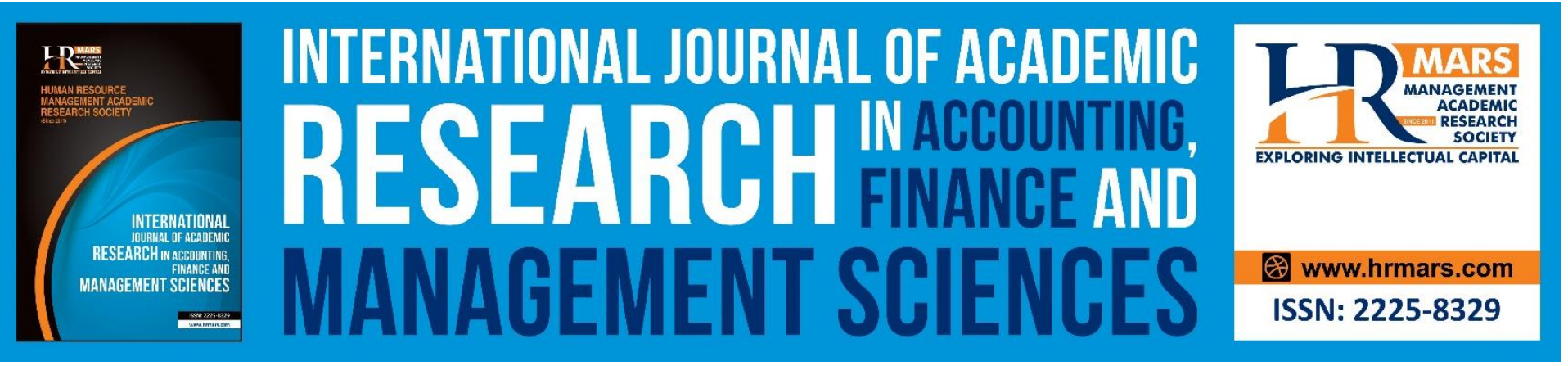

\title{
Effect of Adopting Hardship Allowance Academic Staffs in Jig-Jiga University, Somali Regional State, Ethiopia
}

\author{
Regan Debebe Beluhu \\ Department of Management, Jig-Jiga University, Ethiopia, College of Business and Economics, Jig- \\ Jiga University, Ethiopia. \\ Email: reganadil@gmail.com
}

\begin{abstract}
Higher education is one of the most important drivers of a nation and plays a significant role in the development of any country through the creation and cultivation of knowledge for the sake of building a modern world. The academic staffs are a key resource within higher education institutions. A positive and healthy university structure results in increased academic staff retention, job satisfaction, commitment and better job motivation. The study attempted to examine the extent to which hardship allowance retains and attracts academic staff at Jig-Jiga University (JJU). This study took a mixed method of research design. Primary data were collected through questionnaire surveys and interviews from various fields while secondary data were collected from the website, different journals, books and the internet which related to the hardship allowance. The Questionnaires were administered to a sample of 200 university academic staff while interviews were to university top management officials. The study found that the absence of hardship allowance to JJU's academic staff meant relegating the desired goals of quality education and staff retention. In fact, the existence of such difficult conditions in Jig-Jiga town is duly recognised by different federal institutions operating in Jig-Jiga town. The federal institutions clearly recognise the existence of different difficult working conditions in the town and provided hardship allowance for their employees while their counterpart JJU staffs are getting nothing of such kind. The study offers practical suggestions that deep and urgent attentions need put in place to improve the staffs' life, moral, and motivational crises. Further, the Ministry of Science and Higher education has to oversee the situation like the other sectors that implemented the hardship allowance to their employees.
\end{abstract}

Keywords: Hardship Allowance, Job Satisfaction, Motivation And Job Retention, Academic Staff

\section{Introduction}

Higher education is a key investment in any country as it plays a crucial role in sustainable human and economic development. Thus investment in higher education is widely recognised as a means of supplying the critical human capital required for sustained economic, social and technological 
INTERNATIONAL JOURNAL OF ACADEMIC RESEARCH IN ACCOUNTING, FINANCE AND MANAGEMENT SCIENCES

Vol. 10, No. 3, 2020, E-ISSN: 2225-8329 ๔ 2020 HRMARS

development of a nation. It is therefore important that nations invest heavily in higher education to ensure that the young population is equipped with knowledge, skills and competencies to enable them to contribute meaningfully to national development (Adedeji and Olaniyan, 2011). In Ethiopia, the sector is currently threatened by the brain drain of key professionals which is a concern for improved service deliveries. Academic staff plays a vital role in determining the success of the vision and mission of a university. This is supported by Bentley et al. (2013) who agree that a high-quality academic staff is the source of a successful education system. Therefore, it is important to pay attention to retention, job motivation and satisfaction of the teaching staff. A positive and healthy university structure results in increased academic staff's job set. A healthy university environment will not only increase the job motivation and satisfaction of academic staff, but it will at the same time improve the learning environment and increase the productivity of the university. MachadoTaylor et al. (2010) found that job satisfaction and motivation among academic staff play an important role in contributing to positive outcomes in the quality of the institutions and the students learning. This is true because the success of a university relies on the academic workforce. Khalid et al. (2012) believe that universities are known as the highest source of knowledge where the future workforce is trained to become experts in various field. The performance of academic staff as teachers and researchers determines much of the quality of the student's satisfaction and has an impact on students learning and thus contributes to the higher education institutions of society. Thus, the satisfaction and motivation of the academic staff assume importance. Universities are considered the highest source of knowledge and awareness production institutions that train the subject in different fields of life. Academic staff is comprised of staff members with the primary assignment to instruct research or participate in public serve. They are key resources to the success of any educational programmers. So, motivation, satisfaction among academicians is essential for the success of high educational institutions. It shall be a priority for every employer to keep employees satisfied in their careers.

Bentley et al. (2013) indicate that a healthy climate at university increases not only job satisfaction among academicians, but it also increases the academicians' performance. Nordic (2009) added that a healthy atmosphere in a faculty could be affected by many factors such as healthy working conditions, relationships with colleagues, support in research and teaching appropriate salary, promotion, opportunities, etc. Staff turnover and lack of institutional memories are among the big challenges faced by the institution, which raises questions about the appropriate wage-setting and incentive mechanism. An institution's liveliness whether public or private comes from the motivation of its employees. According to Michaelowa (2002), motivation is the willingness, drive or desire to engage in good teaching. Nelson and Geoffrey (2010) said motivation factors lead to positive mental health and challenge people to grow, contribute to the work environment and invest them in the organisation. Academic performance, on the other hand, is the outcome of education by the extent to which a student, lecturer or institution has achieved their educational goals. The influence of lecturers or teachers' teaching effectiveness on the learning outcome of students as measured by student's academic performance has been the subject of several studies (Adediwura and Tayo, 2007; Victor \& Babatunde, 2007).

Furthermore, viewing the previous literature on teacher's motivation, different authors have explored various issues of motivation for teachers in higher educational institutions. This can be a valuable contribution to enhancing teacher's job satisfaction and involvement in particular and for organisational growth as a whole (Rasheed, Aslam and sarwar 2010).The main purpose of retention 
INTERNATIONAL JOURNAL OF ACADEMIC RESEARCH IN ACCOUNTING, FINANCE AND MANAGEMENT SCIENCES

Vol. 10, No. 3, 2020, E-ISSN: 2225-8329 ๑ 2020 HRMARS

is to prevent the loss of competent employees from the organisation as this could have an adverse effect on productivity and service delivery (Graziano, 2005). Retention activities can be defined as a sum of all those activities aimed at increasing organisational commitment of employees, giving them an overall ambitious and myriad of opportunities where they can grow by outperforming others (De Witte \& Buitendach, 2005). Replacements and training expenses have a direct impact on organisational costs, productivity and performance, as such, an increasing number of organisations now recognise employee retention as a key strategic issue.

In Ethiopia, the manner how and the time when income tax is to be paid to the government is regulated pursuant to income tax proclamation, regulation and directive issued by the house of people representatives, the council of Minister and the Ethiopian Revenue and Custom Authority respectively. Any income derived from hardship allowance is one that is exempted from taxable incomes (Council of Ministers Income Tax Regulation No. 78/2002, Addis Ababa Jul 19, 2002, $8^{\text {th }}$ year No. 37, and article 3(e). Hardship is defined in terms of working in difficult or unpleasant conditions to live and work. Here it is vivid that difficult and unpleasant working condition is not only confined to desert areas. Moreover, the UN International Civil Service Commission has sorted out different factors that have to be taken into consideration to determine the degree of hardship. Accordingly, hardship allowance is determined based on local conditions of safety and security, health care, housing, climate, isolation and the availability of the basic amenities of life (United Nations Common System of Salaries Allowances and Benefits, 2003). This implies that the test of hardship is not determined by taking a single factor. Instead, it is assessed by a test of different factors which are of decisive for decent life condition such as accommodation, water, heating and hygiene.

Similarly, it has also listed various factors that could help to assess whether a region or country is categorised as a hardship location. These factors include physical threat, security, health and medical facilities, remoteness, access to goods and services and housing, among others (Gwavuya, 2011). The purpose behind the hardship allowance is to compensate staff for difficult living conditions in a particular area. It follows that in a hardship location where there are weak infrastructures, high cost of living conditions and housing problems, it is likely that staff repatriation would be very high. That is, the staff would decide to leave their institution and move to better places. Thus, it is commendable to integrate high staff retention mechanisms such as hardship allowances so as to minimise the rate of repatriated employees or staff in an institution. In this regard, various studies advocated and indicated that teacher commitment had been found to be a critical predictor of teachers' performance, absenteeism, attrition, burn out, and turnover, as well as having an important influence on students' achievement and attitudes towards the institution. On the other hand, institutions that provide long promotion ladder, fringe benefits, high wage and job security to their employees are successful even in dog-eat-dog service competition with other institutions (Gwavuya, 2011). Moreover, it is well acknowledged that any nation that is aspiring to maintain high and quality standards or achieve quality assurance in its educational system must take teachers and their motivational needs with the utmost high level of seriousness (Egan, Yang \& Bartlett, 2004). Thus, as hardship allowance is mainly exempted from being taxed to motivate, increase employee's retention rate and as its implementation in higher institution reveals governments' determination to assure a quality educational system, it goes without saying that employees working in unpleasant and difficult working condition should equally be entitled to this incentive.

As Jig-Jiga town is a seat for the regional government, it is inhabited by the population. There are various federal institutions in the town. As the experience of these federal institutions like, Ethiopian 
INTERNATIONAL JOURNAL OF ACADEMIC RESEARCH IN ACCOUNTING, FINANCE AND MANAGEMENT SCIENCES

Vol. 10, No. 3, 2020, E-ISSN: 2225-8329 @ 2020 HRMARS

Airlines, Telecommunication Corporation and Commercial Bank of Ethiopia shows, hardship allowance which ranges from $20-30 \%$ is being paid to the employees of the above respective institutions. This, in fact, begs the question as to why employees of Jig-Jiga University are not getting hardship allowance while their counterpart employees are securing benefits regardless of the similarity of the living condition that they are in. Thus, the different experience and treatment of employees need critical assessment. Accordingly, while hardship allowance privilege is extended for other federal institutions in the Somali region, such as Ethio-Telecom, Ethiopian Airports Enterprise, Commercial Bank of Ethiopia, Ethiopian Electric Power Corporation and Inland Revenue and Customs Authority.

Jig-Jiga University staff though living in a similar working condition with those employees mentioned above, they are not yet benefiting from the hardship allowance. Thus, the practical difference witnessed in Jig-Jiga town with regard to the implementation of hardship allowance deserves due consideration. As is verified by different researches, institutions that provide long promotion ladder, fringe benefits, high wage and job security to their employees are successful even in dog-eat-dog service competition with other institutions (Brown, 2004; Hancock et al., 2013). This is particularly true for those institutions located in areas which are unpleasant and difficult to work, bending to the above employees' benefits is a matter of obligation than choice. Denying these benefits to their employees drastically result in the highest turnover rate, low job satisfaction and thus sub-standard quality services. Thus, it is principal importance to critically investigate the implication of the absence of hardship allowance on Jig-Jiga a University staff job motivation and employee turnover rate. Therefore, the purpose of the study was the effect of adopting a hardship allowance for quality education on academic staff at Jig-Jiga University in the Somali regional state. As the main objective of this research is to investigate the practical implementation of hardship allowance and its implication on Jig-Jiga University civil servants on their job satisfaction, motivation and job retention to achieve this objective, the following specific objectives were raised;

- To critically assess how hardship allowance is treated and determined in the legislations of the country

- $\quad$ To justify the need for hardship allowance on academic staffs

- $\quad$ To assess the living cost of Jig-Jiga town and its impact on academic staffs

- To examine the state of turnover and attrition rate among academic staffs

- To explore the impacts of non-salary benefit on staffs' motivation, job satisfaction, and commitment in relation to quality education

- $\quad$ To empirically assess the practice of hardship allowance in different federal institutions which are located in Jig-Jiga Town

\section{Methodology}

The research adopted a mixed method of research design. The quantitative approach examined the extent to which hardship allowance retains and attracts staff at Jig-Jiga University. The quantitative approach was adopted since the study tried to understand the perception of teachers on hardship allowance effectiveness. The research targeted all academic staff at Jig-Jiga University in Jig-Jiga town. The total numbers of academic staff in the university were 1100, where 200 were considered as sample size respondents. Primary data was collected by use questionnaire surveys and interviews. As the number of high officials in federal and university top management is easy to 
INTERNATIONAL JOURNAL OF ACADEMIC RESEARCH IN ACCOUNTING, FINANCE AND

MANAGEMENT SCIENCES

Vol. 10, No. 3, 2020, E-ISSN: 2225-8329 @ 2020 HRMARS

manage non-probability sampling or purposive sampling was used so that each item in the population was deliberately chosen and included in the sample. However, as the number of Jig-Jiga University staff is difficult to manage, open-ended questionnaires were disseminated to research subjects based on probability or random sampling so that every research subject had an equal chance of inclusion in the sample.

From 200 questionnaires distributed, 113 were properly completed and returned hence a $56.5 \%$ response rate. Therefore, the data were summarised, organised, tabulated, and analysed by using the (SPSS) and descriptive statistics like frequency, and percentages. These frequency tests have been used to further test the mean along with the standard deviations. The data has also been tested in the living condition in Jig-Jiga and intention to leave staff by using chi-square.

\section{Results and Discussions}

\section{Demographic Factor}

The respondents comprised of $31.8 \%$ of female and $68.15 \%$ were male. Married respondents constituted $44.2 \%$ of whom $3.5 \%$ were female and $40.7 \%$ were male. The majority of the respondents were unmarried (55.5\%). Among married respondents, 40 reported that they do have children with the highest number of children being 7 and a mean of 2 children. Moreover, $77 \%$ are breadwinner to their family and have been supporting their family and relatives (dependents). This implies that the majority of the respondents or JJU staffs are shouldering family responsibility while working in JJU. The MSc holders were $41 \%$, followed by BSc holders $33.6 \%$; MA constituted $18.6 \%$ with less than $2 \%$ being PhD holders. The minimum and maximum ages observed were 22 years and 58 years, respectively, with an average age of about 29 years. The maximum work experience was 9 years with a minimum of 1 year while the mean work experience was about 4 years. This implies that the majority of the respondents have substantial experience and understanding of the status and progress of JJU up to its current stand. The interview data also confirmed that thinking and running for the satisfaction of their family, and lack of opportunities to gain income from the side of JJU had reduced the staffs' capacity to fully engage in various research and community service activities in the university.

\section{Environmental based Factors and Motivation of Staff}

About $65 \%$ of the respondents calmed not having additional income gained from paid positions in the university. This implies that the majority of the respondents are leading their life depending only on their salary. Similarly, the data gained from the interviewed department heads indicated that all were not happy with their position, let alone with the income they gain from their paid position. $84.1 \%$ mentioned that they do not have at all any sources of income to support their lives outside their salary and paid position. $92.9 \%$ of other respondents stated that they did not have any income sources outside the salary gained from JJU. This indicates that the staffs of JJU are only dependent on their salary to support their life and their relatives' livelihoods.

Likewise, the interview data supported that except those departments having involvement on CEP program in JJU, almost all interviewees confirmed that there was nothing to be gained as an additional incentive being facilitated by JJU to keep its staff motivated and committed to their job. $9.7 \%$ of female respondents and $80.5 \%$ of male respondents reported that they have monthly housing expenses. Concerning their housing expenditure, the majority of the $90.3 \%$ stated that they have monthly expenses. Respondents reported that the rental price for housing that they have been 
INTERNATIONAL JOURNAL OF ACADEMIC RESEARCH IN ACCOUNTING, FINANCE AND MANAGEMENT SCIENCES

Vol. 10, No. 3, 2020, E-ISSN: 2225-8329 ๑ 2020 HRMARS

paying is not fair from different points of view. Firstly, the houses are not to the standard and they are of low quality and rental charges which is not fair. The house allowance collected from JJU does not match with the empirical renting price staff was paying to the landlords in the city of Jig-Jiga.

The lack of comfort and day to day rent has seriously affected the proper preparation of the staff for classes and their general commitment to their specific duty. About $93.8 \%$ of respondents stated that they have faced housing shortage and affordability more so for the married respondents and having children in comparison to the unmarried ones. Similarly, the interview data confirmed that the affordability of the house rents and the lack of housing services in JJU combined with the price inflation of consumer goods and services in the city forced many of the staff to de-motive with work. The case in Jig-Jiga city seems that housing affordability is very challenging. This is due to the fact that housing expense is the second-largest expenses for the respondents next to food expenses. The respondents reported that housing expenses cost them about $1679 \mathrm{ETB} / \mathrm{month}$ on average. The maximum housing expense reported is $5000 \mathrm{ETB} /$ month. This is really expensive when quality, size and facility of the housing are considered.

Food expense is the largest households' expense noted by the respondents. The mean monthly food expense was reported to be 3945.1327 ETB with a standard deviation of 1538.0. The mean water consumption expense per month was 495 ETB and that taxi was about 300 ETB per month. In addition, the respondents also make financial support to their family and relatives on a monthly basis. Accordingly, the amount of money spent in the form of financial support was 1713 ETB per month, on average. Food expense, water consumption expense, expense on taxi and financial support all together constitute 8135 ETB per month on average. Consequently, $47.8 \%$ of the respondents rated living conditions in Jig-Jiga as hard, while $31 \%$ of them rated very hard. Only $4.4 \%$ and $1.8 \%$ of the respondents rated living in Jig-Jiga as good and very good respectively. The relationship between the perception of living conditions in Jig-Jiga and its impact on workers' turnover intention is statistically significant at a $5 \%$ level of significance. Therefore, results reveal that $17.7 \%$ of the respondents who perceive that living condition in Jig-Jiga were hard having an intention to leave JJU after they accomplished their contracts. On the other hand, $14.2 \%$ of the respondents who rated the living condition of Jig-Jiga as very hard intend to leave after accomplishing their commitment.

Evidence shows that consumer goods are not available to the required quantity and quality in JigJiga. $81.4 \%$ of the respondents ( $8.8 \%$ female and $72.6 \%$ male) responded that consumer goods are not available to the required quantity and quality in Jig-Jiga.

It was noted that $13.3 \%$ of the respondents get piped water while the remaining get water from nonpiped sources which are unsafe. About $79.6 \%$ of the respondents reported that they buy bottled water such as Fafan and Aqua Dire for drinking and depend on water vendors ('biyole') for other purposes. This implies that still, the respondents lacked basic rights associated with clean water. The reason why the respondents buy bottled water for drinking was that, as per the view of the respondents, the available water, even the piped one was not potable as reported. $74.3 \%$ of the respondents reported that the water that they get. The water that was bought from the biyoles was not well treated hence unhealthy. The association between the difficulty and cost of living in Jig-Jiga with workers' turnover intention was analysed. Evidence showed that workers prefer locations with comfortable and cheap living standards. Almost all $95.6 \%$ of the respondents believed that living in Jig-Jiga was difficult and costly. Due to this fact, $39.8 \%$ of these respondents had a plan to quit renewing their contractual agreement with JJU after accomplishing their current contracts. This implies that the majority of the respondents are living and working with the plan on their mind to 
INTERNATIONAL JOURNAL OF ACADEMIC RESEARCH IN ACCOUNTING, FINANCE AND MANAGEMENT SCIENCES

Vol. 10, No. 3, 2020, E-ISSN: 2225-8329 ๑ 2020 HRMARS

leave after their commitment. It was not their goodwill and interest that has kept them to stay in JJU but their service year expected from them. Similarly, the data revealed that at least on each interviewed department, there are formal requests of transfer cases. Another factor affecting the intention of the respondents to leave is additional benefits/income related to the workers' current job. In line with this, we tried to find out whether an additional income affects workers' turnover intention or not. Thus, results reveal that about $84 \%$ of the respondents do not have additional income and only $16 \%$ of them earn additional income. Among those who reported not get additional income, $37.9 \%$ of them have the intention to leave after accomplishing their contract term. Confirming this observation, the data indicated that almost all interviewed departments at least one can find from one to two legal transfer cases to other universities. People put great value on their health and want to get access to quality hospitals. $25.7 \%$ of the respondents perceived the quality supply of hospitals and medical supplies in Jig-Jiga town, while $74.3 \%$ of the respondents stated that there was no quality and medical supplies. It implies that getting quality medical treatment in Jig-Jiga was the worry of the majority of the respondents.

Experiences of different countries show that hardship allowance is permitted based on different conditions. These are remoteness of the working area, cost of living, security, harsh climate and the like. This implies that harsh climate condition is not the only criteria for hardship allowance. The result that the respondents put forward confirms the same truth. It shows that $89.4 \%$ of the respondents replied that hardship allowance does not depend only on harsh climate conditions. There are other critical points on which the concerned bodies should focus on devising hardship allowance programs. Denying hardship allowance for the fact that there is a pleasant climate condition may highly affect the living standard of the workers as well as productivity as other conditions such as the cost of living also matters a lot.

It is known that there is a high cost of living differential among different cities of Ethiopia. Wage premiums should be considered if the living cost differentials among these cities are significant. This is the reason why some federal government organisations and NGOs in Ethiopia are paying wage premiums to their employees. In line with this, $84.1 \%$ of the respondents have information that some federal government organisations and NGOs located in Jig-Jiga have been paying hardship allowances to their staff compensate for the cost of living of their employees. The income and expenditure analyses conducted so far show that it is very difficult for the majority of the respondents to cope with the current cost of living. Moreover, access to a tap and potable water, access to quality hospitals and medical supplies, access to consumer goods like fresh fruits, access to recreational centres and quality schools for children is very limited. This makes the households feel that they deserve to get a hardship allowance to tackle the difficulties. Accordingly, $94.7 \%$ of the respondents believe that they deserve to get the hardship allowance if the living condition and cost of living in JigJiga is considered. Denying it highly impedes the quality of education and this is supported by about $93 \%$ of the respondents.

\section{University-Based Factors}

Literatures document that paying hardship allowance significantly improves teachers' satisfaction with their income and job satisfaction. This, in turn, reduces the incidence of teachers holding outside jobs (and the hours worked on them) and reduces self-reported financial stress which plays a great role in reducing employees' job turnover and improves the quality of education. It is also a belief of $93 \%$ of the respondents that hardship allowance will reduce the turnover rate. If hardship allowance 
INTERNATIONAL JOURNAL OF ACADEMIC RESEARCH IN ACCOUNTING, FINANCE AND MANAGEMENT SCIENCES

Vol. 10, No. 3, 2020, E-ISSN: 2225-8329 ๑ 2020 HRMARS

is permitted, $97.3 \%$ of the respondents are willing to serve JJU even after the accomplishment of their contractual commitment. In regard to the current state for requested transfer cases, interviewees cited various reasons why JJU staffs are still requesting for transfers. For instance, the zero-request case in some department does not mean the request is absent, rather by the time the data has been collected, the university had stopped accepting transfer requests.

Interviewees invariably expressed that the request for transfer and the rate of turnover at the university is high. Difficult working conditions deemed to affect teachers' personal life that forces them to leave the place through all means they could. The staffs' retention, transfer and turnover at JJU interviewees' response fell in between too happy and not happy with their stay at Jig-Jiga University. When asked to state the reason for happiness, some described that in comparison to other universities in Ethiopia, JJU gives more golden opportunities for its staff to engage in research and upgrade their educational status. However, they also noted that these days the life condition in the city had made their life to worsen. Whereas, those who are against the first view attributed their unhappiness to lack of basic services like housing, enough transportation services and lack of health facilities and that of poor management has made their stay to worsen. According to Bennell and Akyeampong (2004), only when these basic needs have been met is it possible for higher-order needs, which are the basis of true job satisfaction, to be realised. One interviewee strongly argued that there is nothing that motivates him as the money remains the most motivational factor. He is indifferent to the physical surrounding of the workplace and very dissatisfied with his wage or salary.

The staff expressed their views that their inadequate salary is one of the major factors that affect their job dissatisfaction and motives. It is too low for individual and household survival needs to be met in the town. Furthermore, the interviewees further evidenced their point of arguments by comparing and contrasting Jig-Jiga university from similar sister universities like Dire Dawa and Samara university. Dire Dawa and Samara University have hardship allowances. For example, teachers get a $40 \%$ hardship allowance at Samera University. Life is very cheap at Dire Dawa compared to Jig-Jiga.

Almost all of the respondent with the exception of some of the head of departments, they said that there is nothing to motivate the staff from the side of JJU. Some of the staff that are having involvement in CEP and other projects mentioned as one motivating incentive that has been done by Jig-Jiga university to keep its staff being motivated. Likewise, still others mentioned that having academic freedom at Jig-Jiga University by itself is one motivating factor to stay in the university.

The interviewees explained that the major challenges of Jig-Jiga university staffs facing are ranging from the lack of basic services needed to the teaching-learning process to that of the administrative bureaucracy. Taking in to account the varied nature of the challenges the researcher has stated the top ones as follows: lack of housing, lack of toilet, lack of offices for Ph.D and senior staffs, lack of water for hand after class, lack of transparency on scholarship and project-related areas, lack of entertainment places, poor respect for academic staffs from the management, getting overloaded with teaching alone and lack of separate transportation service for staff. In other words, the interviewees revealed that as it could be very difficult to survive with a one-time monetary in the town, the quest for additional benefits began from the establishment of the university (for the past ten years). It has been ideal that even basic necessities are lacking or unaffordable in the town that made the civil servants felt dissatisfied. As a result, teachers leave for the search of greener pastures, or they may be compelled to remain in their job. It is difficult for them to live in the town. More than $75 \%$ of their salary has been spent on basic needs; while housing and food took the lion's share. It is 
INTERNATIONAL JOURNAL OF ACADEMIC RESEARCH IN ACCOUNTING, FINANCE AND MANAGEMENT SCIENCES

Vol. 10, No. 3, 2020, E-ISSN: 2225-8329 @ 2020 HRMARS

hard to save though both of them are bachelors. However, the participant has dependents that he regularly supports what he receives every month.

Then again, the interviewees revealed that the strengths of JJU to keep its staff energised and motivated should be made. Although there have been a lot of challenges that keep JJU staff to remain unsatisfied or to leave the university in the form of termination or legal transfer, still there are some positivity to be appreciated and keeps on progress. Some of these strengths are stated as follows: academic freedom in comparison to other young universities, transparency on department and vice dean election, refreshment services for all department staff, internet accessibility with its connection problem, support community services, extension and weekend educational opportunities and campus greening projects. Respondents exposed that current performance status at Jig-Jiga University was low. The data acquired from the informants indicated that most of them are not performing their jobs to the best of their capacity. The major reasons for this are the staffs' involvement in routine teaching-learning activities than engaging in research and community service areas. Similarly, some of them state that the existence of limit on the research thematic areas of JJU and the serious lack of reading offices with properly functioning with the internet has become another factor in sticking us on teaching-learning activities alone.

Additionally, the interviewees said that the basic things to be fulfilled by JJU similar to any other universities in the country. Up on gathering of the data, taking into account the nature of the things available in other universities within the country, almost all of the informants agreed that the following things have to be fulfilled by the university such as housing, respect for academic staffs, toilet, internet with maximum capacity, offices for $\mathrm{PhD}$ and senior staffs, separate transportation service for academic staffs, water, soap, and soft tissue for after class cleaning, scholarship and short term training program, incentives taking into consideration where the university has located. The department heads stated that they are not happy and satisfied with their current position; rather, they regard their position as an imposition on them from the top management. Similarly, some of them indicated that having the position by itself does not matter, because the power associated with the position is absent and you do not have full authority to exercise.

The interviewees said that there are a lack of hardship allowance and the need for incentives. Bringing evidence from the legal documents and describing the environmental location of the university almost all staff has mentioned that the absence of hardship in JJU has an implication on their stay, performance, motivation, and level of satisfaction with their jobs. when they point how the hardship absence has affected their academic life, one head of the department said that "how am I supposed to think about my living cost while I am expected to think about research as a university lecturer." Similarly, another head indicated that if hardship allowance is implemented in JJU, none of us will run to search for additional jobs to support our life outside the university. Furthermore, others stated that the presence of hardship in JJU would reduce our economic problem and worry about our daily needs. Its presence can also keep me safe and commit myself as the city (Jig-Jiga) is the centre of business; it is hard for teachers to live with their monthly salaries. One interviewee living in the town revealed that:

I have faced a life of hardship due to the inadequate salary that could not afford quality houses and utilities. The quality and availability of suitable housing and utilities as well as the distance between Jig-Jiga town and the capital could have an adverse effect on me and my dependents. The cost of utilities (like house rent, food, water, etc.) is increasing from time to time. Although there had been 
INTERNATIONAL JOURNAL OF ACADEMIC RESEARCH IN ACCOUNTING, FINANCE AND

MANAGEMENT SCIENCES

Vol. 10, No. 3, 2020, E-ISSN: 2225-8329 @ 2020 HRMARS

improvements made with salary increments, it is not enough. Long term incentives need to be in place for teachers' retention here. It should make them hope to live and lead a stable life.

Further noted that he had internal satisfaction as he has been serving his nation. However, what made him often worry is the challenge impeding him to have family and supporting his dependents as he wishes.

Finally, the practical implementation of hardship allowance in Jig-Jiga town with different federal institutions operating in Jig-Jiga town that pays hardship allowance to their employees which the legal basis that justifies hardship allowance for the employees of those institutions such as EthioTelecom, Commercial Bank of Ethiopia, Ethiopian Electric Power Authority. Therefore, the researcher had an extensive interview with the managers, human resource heads and finance heads of the respective institutions. So as to know whether the Ethio-Telecom Jig-Jiga branch is actually paying hardship allowance to employees working in Jig-Jiga town, the researcher conducted an in-depth interview with a representative Chief Executive Officer (CEO) of Ethiopian Somali regional state telecom. The CEO revealed that Ethio-Telecom is paying a $35 \%$ hardship allowance to its employees. He further tries to explain that unlike the hardship allowance provided under income tax legislation, which is tax-free, the hardship allowance that the corporation is paying is subject to tax. He also further noted that the hardship allowance is being paid based on the circular letter sent from the head office in accordance with the decision of the board. Paying hardship allowance to employees working in Jig-Jiga, the manager put that as Jig-Jiga town is not geographically categorised under desert as the law requires, it is legally impossible to pay hardship allowance to employees working in Jig-Jiga Town. But he adds that in order to retain and attract human resources in the market, payment of hardship allowance is inevitable. Because, facts on the ground show that there are various unpleasant conditions to the employees working in the town, such as the living cost of the town, the unavailability of pure drinking water and affordable house rent, the fact that the town is located in the emerging regional state and the like, he goes on explain that the corporation has come up with another mechanism other than already provided under income tax proclamation that relates hardship with desert areas. Finally, the manager has explained the significance of hardship allowance in retaining the employees by saying that paying hardship allowance for employee working in a harsh environment is considered as a source of stimulation to the employee to stay in a particular organisation.

In the context of Jig-Jiga town, hardship is not about bad weather or being a desert; rather it's about living cost, quality service and generally related with once capacity to cope with the market to satisfy his/her daily basic needs. Therefore, high living cost and when the quality of service is poor employees needs extra payment as an incentive to stay in an organisation found in such area. He explained this by asking that since Ethio-telecom has a number of branched in towns where the infrastructure is well developed, how can you retain employees working in Jig-Jiga with less infrastructure without giving an extra incentive than those living in well-developed towns? We can call such extra payment as a hardship allowance, which takes into consideration the actual working condition on the ground. Finally, he concludes that 'with no doubt, such payment plays its role among other factors to reduce employee turnover rate of an organisation.

The second federal institution selected is CBE in Jig-Jiga town. The researcher asked whether CBE is paying hardship allowance for employees working in Jig-Jiga branches, the manager of the bank assured that the bank pays a $20 \%$ hardship allowance to its employees. As far as the legal basis of this extra payment is concerned, the manager said that it was decided at head office level, in Addis Ababa 
INTERNATIONAL JOURNAL OF ACADEMIC RESEARCH IN ACCOUNTING, FINANCE AND MANAGEMENT SCIENCES

Vol. 10, No. 3, 2020, E-ISSN: 2225-8329 ๔ 2020 HRMARS

to pay the hardship allowance. He also went on sating that all private banks as well as nongovernmental organisations (NGOs) operating in Jig-Jiga town pay additional hardship allowance to their employees. He even criticises the confinement of hardship allowance only with desert areas by stating other different factors that can make places unpleasant and difficult to work. For example, he states that 'employees working in Dire Dawa get 30\% hardship allowance because of the hot climatic condition of the town'. But he adds that in terms of getting potable drinking water, affordable rent house and the living cost of the town is incomparable with Jig-Jiga town where you can hardly get all the aforementioned services easily. Therefore, the manager concludes that if we need to provide quality service among other factors, it is a must to have a satisfied employee and an employee who can afford the cost of living at his/her duty station. For him, providing additional payment in the form of hardship allowance in towns like Jig-Jiga plays an immense role in the retention of employees.

The other federal institution working in Jigjig town is, EEPA. Hence, the researcher conducted an open-ended interview with the head of the human resource of EEPA Jig-Jiga branch. The researcher inquired about whether the organisation is paying hardship allowance to its employees. The HR manager confirmed that EEPA is paying $20 \%$ extra money as a hardship allowance to employees working in Jig-Jiga town. He adds that EEPA is aware of the fact that Jigjig town is among those towns in which various difficult conditions such as high living cost, unavailability of affordable rent house, lack of clean drinking water and other similar difficult problems are rampant. Accordingly, by taking the existing difficult condition of Jig-Jiga town, EEPA has decided to give $20 \%$ of the hardship allowance to its employees. The manager also noted the importance of payment of hardship allowance for retention of employees in areas like Jig-Jiga in which employees face difficulties with regard to getting different basic necessities. Thus, according to him, the need to provide additional incentives in the form of hardship allowance to compensate such difficult factors is of paramount importance for the retention and satisfaction of workers.

\section{Conclusion}

While earnings, benefit levels and taxation all attracts a large amount of commentary, living costs have been relatively overlooked in recent living standards debates. The data from the staffs of JigJiga- confirmed that for the vast majority of the staff revealed that housing costs comprise the single largest expenditure they payout which evaporates the benefits of growth the increase in their housing costs outpaces their income growth. The case in Jig-Jiga city seems that housing affordability is very challenging. This is due to the fact that housing expense is the second-largest expenses for the respondents next to food expenses. The respondents reported that housing expenses cost them about 1679 ETB/month on average. Likewise, food expense is the largest household's expense as the data reveals. The mean monthly food expense is reported to be 3945.1327 ETB with a standard deviation of 1538.01479. The mean water consumption expense per month is 495 ETB and that taxi is about 300 ETB per month.

High expenses and meagre additional income in addition to other factors make staff turnover intention in JJU very high. Job satisfaction is one of the factors affecting turnover intention, which is in turn, affected by the working environment and living conditions. Living condition in Jig-Jiga is perceived as hard and very hard by the majority of the respondents. This situation positively affects workers' turnover intention. A significant number of JJU staff intends to leave after accomplishing their contractual commitment. Therefore, the imbalance between income and expenditure for JJU staff shows that it is very difficult for the majority of the households to cope with the current cost of 
INTERNATIONAL JOURNAL OF ACADEMIC RESEARCH IN ACCOUNTING, FINANCE AND MANAGEMENT SCIENCES

Vol. 10, No. 3, 2020, E-ISSN: 2225-8329 @ 2020 HRMARS

living. Moreover, access to a tap and potable water, access to quality hospitals and medical supplies, access to consumer goods like fresh fruits, access to recreational centres and quality schools for children is very limited. This makes the households feel that they deserve to get a hardship allowance to tackle the difficulties.

The contribution of this research is the principle role of the universities which recognizing the needs and the desires of academic staff based on various working situations and meeting those needs according to the organization's policies. In reality, the universities should have adequate consciousness and knowledge for preparing and developing appropriate atmosphere among academic staff and realizing their tendencies and needs from workplace. All of these education organizations need to provide appropriate facilities for their staff. In this study make a valuable contribution to the awareness of understanding the concept of job satisfaction, retention and the effect of the motivation on hardship allowance. However, additional research is needed for further investigation of the potential relationship and effects that these variables and other variables have on job satisfaction. That means that different cultures with their own values, religion, and socioeconomic status may have an impact on research findings.

The adoption of hardship allowance is believed to have significant impact supporting the staffs' difficult cost of living and in positively influencing students' academic performance. Generally, the study is believed to be important for the following reasons; It serve as a useful input for JJU administration and academic staff association to deal with the concerned bodies and thus solve the problem. It provides relevant information on the effects of the absence of hardship allowance on the teaching learning process and the overall missions of the university. It benefits JJU employees in voicing their concern over the unfair distribution of hardship allowance. It worthy in pinpointing the implication of the absence of hardship allowance for quality education and staff retention. The adoption of hardship allowance is motivating instructors to enjoy working in JJU. By upgrading job satisfaction, the adoption of hardship allowance is diminish resignation and transfer requests and thus tackle staff retention crisis. The research helps the concerned bodies to rethink the necessity of extending hardship allowance for JJU staffs.

\section{Suggestion for Future Research}

Based on the findings of the study, it appears to be reasonable to make the following suggestions as an agenda for action. First, the bodies concerned need to determine the scope and practical implementation of hardship allowance with an explicit legal framework that takes into account all the factors affecting the amenities of teachers' life in higher institutions. More specifically, JJU academic staff confronted big challenges which result in developing poor morale and low levels of commitment, due to the difficulties to cope with others in Jig-Jiga Town as the town is the centre of business. Thus, deep and urgent attentions have to be in place to improve the staffs' life, moral, and motivational crises. The researcher suggests that a true measure of housing affordability must capture both the ability to enjoy a satisfactory standard of housing and to have enough left over to meet other basic living costs. The academic staff, for a decade, made attempts to discharge their responsibilities with several inconveniences; like shortage water and housing, to mention a few. Therefore, the Ministry of Education and all the concerned bodies have to oversee or consider the situation like the other sectors that implemented the hardship allowance to their employees. Currently, above all, quality issues are the basic concerns of this country, and the absence of hardship 
INTERNATIONAL JOURNAL OF ACADEMIC RESEARCH IN ACCOUNTING, FINANCE AND

MANAGEMENT SCIENCES

Vol. 10, No. 3, 2020, E-ISSN: 2225-8329 @ 2020 HRMARS

allowance to JJU's academic staff meant relegating the desired goals of quality education and staff retention.

\section{References}

Adedeji, S. O., \& Olaniyan, O. (2011). Improving the conditions of teachers and teaching in rural schools across African countries (pp. 1-89). Addis Ababa: UNESCO-IICBA.

Adediwura, A. A., \& Tayo, B. (2007). Perception of teachers' knowledge, attitude and teaching skills as a predictor of academic performance in Nigerian secondary schools. Educational Research and Reviews, 2(7), 165-171.

Bennell, P., \& Akyeampong, K. (2007). Teacher motivation in sub-Saharan Africa and South Asia (Vol. 71). London: DfID.

Bentley, P. J., Coates, H., Dobson, I. R., \& Meek, V. L. (2013): Factors associated with job satisfaction amongst Australian university academics and future workforce implications. In Bentley, P., Coates, H., Dobson, I., Goedegebuure, L. \& Meek, V. (eds) Job Satisfaction around the Academic World (pp. 29-53). Dordrecht, Netherlands: Springer.

Brown, W., Yoshioka, C. F., \& Munoz, P. (2004). Organizational Mission as a Core Dimension in Employee Retention. Journal of Park \& Recreation Administration, 22(2).

De Witte, H., \& Buitendach, J. H. (2005). Job insecurity, extrinsic and intrinsic job satisfaction and affective organizational commitment of maintenance workers in a parastatal. South African Journal of Business Management, 36(2), 27-37.

Egan, T. M., Yang, B., \& Bartlett, K. R. (2004). The effects of organizational learning culture and job satisfaction on motivation to transfer learning and turnover intention. Human resource development quarterly, 15(3), 279-301.

Graziano, C. (2005, Feb 9). Public Education Faces a Crisis in Teacher Retention. Retrieved from Editorial, available at https://www.edutopia.org/schools-out

Gwavuya, F. (2011). Leadership influences on turnover intentions of academic staff in tertiary institutions in Zimbabwe. Academic Leadership: The Online Journal, 9(1), 36-50

Hancock, J. I., Allen, D. G., Bosco, F. A., McDaniel, K. R., \& Pierce, C. A. (2013). Meta-analytic review of employee turnover as a predictor of firm performance. Journal of Management, 39(3), 573603.

Khalid, S., Shad, M. Z. \& Mahmud, B. (2012): Job satisfaction among academic staff: A comparative analysis between public and private sector universities of Punjab, Pakistan. International Journal of Business and Management, 7(1), 126-132.

Machado-Taylor, M. L., Meir Soars, V., \& Gouveia, O. (2010). The role of job motivation among academic staff university. Global Business and Economics Anthology, 2(2), 242-246.

Michaelowa, K. (2002). Teacher job satisfaction, student achievement, and the cost of primary education in Francophone Sub-Saharan Africa (No. 188). HWWA Discussion Paper No. 188. Hamburg Institute of International Economics.

Nelson and Geoffrey (2010). Motivation and Academic Staff Performance in Public

university in Uganda: The Case of Maker ere University. Retrieved from http://dspace.mak.ac.ug/handle/123456789/1339

Nordic, F. (2009). Levels of job satisfaction amongst Malaysian academic staff. Journal of Asian Social Science, 5(5), 122-128. 
INTERNATIONAL JOURNAL OF ACADEMIC RESEARCH IN ACCOUNTING, FINANCE AND MANAGEMENT SCIENCES

Vol. 10, No. 3, 2020, E-ISSN: 2225-8329 @ 2020 HRMARS

Rasheed, M. I., Aslam, H. D., \& Sarwar, S. (2010). Motivational issues for teachers in higher education: A critical case of IUB. Journal of Management Research, 2(2), 1.

Victor, A. A., \& Babatunde, E. G. (2014). Motivation and Effective Performance of Academic Staff in Higher Education (Case Study of Adekunle Ajasin University, Ondo State, Nigeria). Online Submission, 1(2), 157-163. UN (2003). United Nations Common System of Salaries, Allowance and Benefits. 